\title{
The Development of Learning Media Based on Augmented Reality, Hologram, and Ludo Game on The Topic of Molecular Shapes
}

\author{
https://doi.org/10.3991/ijim.v16i04.28989 \\ ${\text { Rifqon Hakiki }{ }^{1}, \text { M. Muchson }}^{1,2(\mathbb{\otimes})}$, Oktavia Sulistina ${ }^{1}$, Asia Febriana ${ }^{1}$ \\ ${ }^{1}$ Faculty of Mathematics and Natural Sciences, Universitas Negeri Malang, East Java, Indonesia \\ ${ }^{2} \mathrm{PhD}$ Student in Mallinson Institute for Science Education, Western Michigan University, \\ Kalamazoo, USA \\ m.muchson. fmipa@um.ac.id
}

\begin{abstract}
This Currently, technology-based learning media is needed to attract students' learning interest. Augmented Reality and Hologram, both technologies are able to answer these problem. In addition, the Ludo Game can also increase the student's learning interest when applied as a learning media. This study aims to: developing a learning media based on Augmented Reality, Hologram, and Ludo Game on the topic of molecular shapes, as well as knowing the feasibility of this learning media. Research and Development (R\&D) is used as research methods. The development of media adapted the ADDIE model, which includes the stage: assessment/analysis, design, development, implementation, and evaluation. The feasibility of this learning media is based on the results of product validation as a learning media, material, and small group trials of 17 Senior High School students. The results of study found that the percentage of product validation results as a learning media is $85,56 \%$ (very feasible), material is $88,00 \%$ (very feasible), and small group trials is $87,25 \%$ (very feasible). Based on this, it can be concluded that this learning media is very feasible to be implemented in the study on the topic of molecular shapes.
\end{abstract}

Keywords—augmented reality, hologram, learning media, ludo game, molecular shapes

\section{Background}

Education is one of aspects that determines the future and is given to educate the nation's life. The high quality of education can affect the quality of Human Resources (HR). According to the Cable News Network (CNN) Indonesia data set, the UNESCO Education Index (2016) stated that the quality of education in Indonesia ranks 108th in the world (Solihin, 2017). While at the ASEAN level, it was in the 5th position, which was under Singapore, Brunei Darussalam, Malaysia, and Thailand. The low quality of education in Indonesia is not only caused by a lack of efficiency, infrastructure, relevance, and equity of education, the implementation of the 2013 curriculum 
which is centralized and always undergoing policy changes also triggers sudden adjustments in the implementation of learning for all subjects in schools, causing less than optimal learning in the classroom, for example such as learning chemistry material (Naibaho, 2015).

Chemistry subject matter is still considered a difficult subject by some students. This is because most of the concepts of learning chemistry are submicroscopic and abstract which are specifically introduced in Senior High School. One of the submicroscopic and abstract chemistry materials is molecular shapes. This is evidenced by the many misconceptions that occured in students according to several studies. Based on research (Ayni, 2019), most of the students of class X MIPA 3 SMA Negeri 1 Sungai Pinyuh, Indonesia, still have difficulty determining molecular shapes from several assessment indicators. This research was conducted with the number of respondents used as many as 32 students. More than $60 \%$ of students still have difficulty in determining the shape of a molecule because they have not mastered several prerequisite materials in chemical bonding which include: determining electron configuration, bonding electron pairs, lone pairs, molecular shapes, and writing VSEPR notation.

The results of Hayati's research (Hayati, 2020) on 31 students of class X MIPA MAN 3 Banda Aceh about the achievement of students understanding the material of molecular shapes, used the FTMC (Four-Tier Multiple Choice) test sheet instrument, showed that only $22.32 \%$ of students understood the concept, while the remaining $77.68 \%$ did not understood the concept, some even have misconceptions. Most of the reason is that students have difficulty to understanding the concept of bonding in molecules, so they cannot to predict and/or determine the molecular shape of a compound. The feeling of anxiety of students who have difficulty understanding this material is one of the intrinsic factors that can cause students' interest and motivation to decrease (Siregar \& Nara, 2014), which has implications for low student learning (Nurdin \& Sulastry, 2018). Therefore, we need an interesting teaching solution using interactive learning media that supports the material. However, the practice of learning in chemistry, especially molecular shapes, is limited to the level of verbal explanation and the use of textbooks, but not visually (Anwar, 2014). Therefore, interactive learning and media are needed that can facilitate students' imagination in accepting molecular shapes material (Riku, 2021). One way is to use learning media based on technology and games.

The development of science and technology continues to encourage various reform efforts for the use of technological results in the learning process (Arsyad, 2014). For example, Augmented Reality and Hologram technology, are two technologies that both function to project/display objects in three dimensions with different components and can be applied to interactive digital products (Carrozzi et al., 2019). Based on the functions they have, Augmented Reality and holograms have the potential to be developed into interactive learning media on molecular shapes material that require three-dimensional visualization (Fitriani, Suhartono, \& Mugiarti, 2019). Augmented reality can make students confirm whether their imaginations are true to the visuals of molecular shapes that have been imagined before. In addition to these two technologies, traditional games such as ludo games can also be used as interactive learning media on the topic of molecular shapes (Yuberti, Sairi, Nanto, \& Sholeha, 2020).

Ludo game is a type of game that can to create a sense of fun and entertaining if done (Kristiani, 2015). Ludo games in learning can also create a fun learning atmosphere 
(Lestari \& Iswendi, 2021), and ludo games can increase students' enthusiasm and motivation in learning because they are unique in the structure of the game (Fadillah, 2019). Therefore, the ludo game has the potential to be used as a learning media, especially on molecular shapes material with additional Augmented Reality and Holograms features as visual support for the material.

Based on the problems in the implementation of the learning of molecular shapes material above, the solution that can be done is to use learning media based on Augmented Reality, Holograms, and ludo games. Augmented Reality and Hologram features can help students understand the concept of matter by displaying a three-dimensional simulation of molecular shapes accompanied by some other information. The Ludo game feature serves as a medium to help students to increase their curiosity and motivation in learning. If these three features are combined into a complete set of learning media, it is hoped that the teaching of molecular shapes material can be easily to carried out and become more easily understood by students.

\section{Methods}

The method used in this research is Research and Development (R\&D). Learning media based on Augmented Reality (AR), Holograms, and ludo games on molecular shapes material was developed by adapting the development model according to (Lee \& Owens, 2004), namely the ADDIE learning media design model, which includes stage of assessment/analysis, design, development, imple mentation, and evaluation (Agustina Dwi Astuti, Asep Sumarni, \& Luhur Saraswati, 2017). The procedure of media development can be seen in the following flow chart.

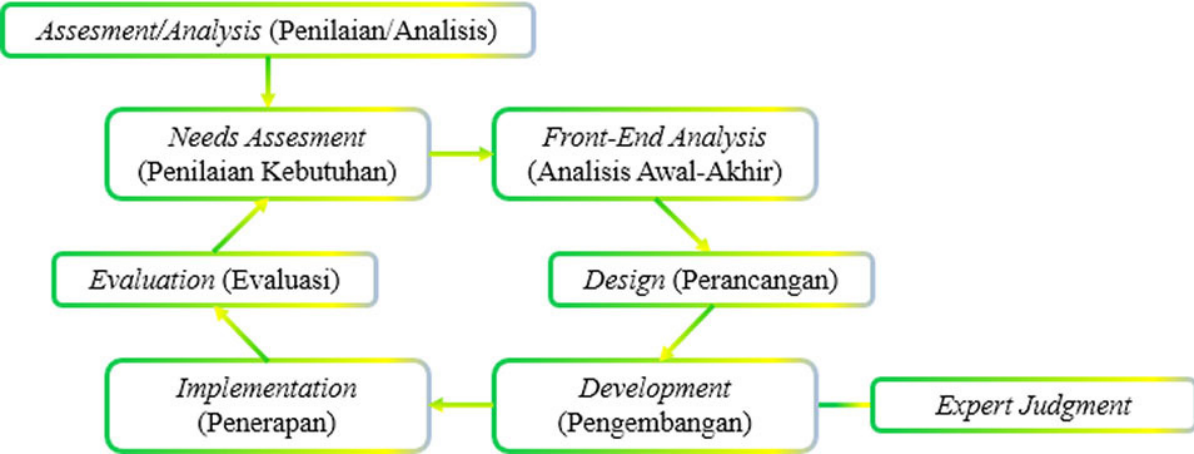

Fig. 1. Media development procedure flowchart

At assessment/analysis stage, an analysis is carried out to found out the basic problems of media development and defined the needs in the learning process. After that, the determination of (1) target media users, namely for Senior High School students/ equivalent, (2) learning objectives and media materials, in this case the selected material was molecular shapes, and (3) technology and components were needed in developing this learning media, include: Augmented Reality (AR), Holograms, and complete components of the ludo game. 
The design of the selected material structure, validation and small gorup testing tools were carried out at design stage. The material was arranged sequentially starting from the chemical bond submaterial, then the molecular shapes, and later the material can be accessed nonlinearly depending on the submaterial you want to study when the media is used. The validation and small group testing tools were arranged in the form of a fivelevel Likert scale questionnaire (Saregar et al., 2019). This questionnaires was filled by material experts, media experts, teachers, and students.

Media development began with storyboarding. Storyboard is the design of an application that is arranged sequentially and is equipped with an explanation of each image, screen, and text (Andreas, 2013). Storyboard was designed by making the appearance and content of the media according to the objectives that have been formulated previously. Then created the physical learning media in the form of a ludo game with the required components. Furthermore, media programming was carried out according to the storyboard that has been made. The programs used in the development of this media are: (1) Chemdraw and Chemspider to designed the initial material, (2) Babel and Meshlab/blender to displayed 3D animation and designed the required features, and (3) Unity Pro to designed applications that was exported in format final apk, so that it can be applied on android.

The learning media that has been developed is then validated and tested in small groups to determined the level of feasibility of the media. The validation was carried out by media experts, material experts, and chemistry teachers of SMAN 1 Turen, while the small group trials was carried out by 17 students of grade 10th SMAN 1 Turen. The data obtained were analyzed by percentage analysis technique using the following formula (Asyhari \& Silvia, 2016):

$$
\mathrm{P}=\frac{\sum x}{\sum x i} \times 100 \%
$$

Description:

$\mathrm{P}=$ percentage of eligibility/validity

$\sum x=$ total score of validator answers

$\sum x i=$ total number of highest answer scores

To found out the conclusions from the results of the calculation of the average percentage above, a range of validation or feasibility criteria was used which refered to the feasibility criteria below:

Table 1. Scale of feasibility criteria (Riduwan, 2012)

\begin{tabular}{|l|l|}
\hline \multicolumn{1}{|c|}{ Percentage (\%) } & \multicolumn{1}{c|}{ Criteria } \\
\hline $0-20$ & Highly not feasible/valid \\
\hline $21-40$ & Not feasible/valid \\
\hline $41-60$ & Quite feasible/valid \\
\hline $61-80$ & Feasible/valid \\
\hline $81-100$ & Highly feasible/valid \\
\hline
\end{tabular}

The final stage, evaluation was done by reviewing product development at each stage, analyzing data based on the results of product validation and small group trial, and revised products based on comments and suggestions given by the validator. 


\section{$3 \quad$ Results and discussion}

The final result of the development of learning media based on Augmented Reality, Hologram, and ludo game on the molecular shapes material for Grade 10th Senior High School/equivalent students in the physical media of the Ludo board game, and application with the final format .apk. The results of physical media namely: pawns, dice, ludo game board, holographic glass prisms, holographic video set, information cards, question cards, more information cards, and manual book.

\subsection{Physical learning media product}

This product is a learning media with a complete set, which contains: dice, pawns, a ludo game board containing boxes of four different colors. In this learning media, the number of dice is one, while the pawns is 16 pawns. Ludo board game design was modified from the usual board game design. The $6 \times 6$ grid track was trimmed to a $4 \times 4$ grid track. This learning media is in the form of poster paper prints measuring $50 \mathrm{~cm} \mathrm{x}$ $50 \mathrm{~cm}$. This print will later be affixed to a chessboard measuring $52 \mathrm{~cm} \times 52 \mathrm{~cm}$ which has been previously designed and is given an additional magnetic feature.

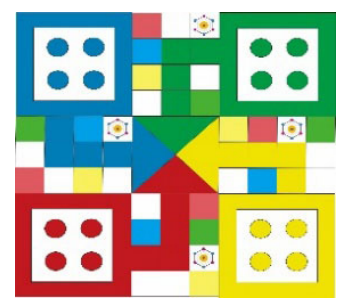

Fig. 2. Design of media game board

Each home box on the learning media was made in different colors, namely blue, green, yellow, and red. The four colors are bright colors, which were chosen because these colors can to increase students' enthusiasm in learning (Atikah \& Alwi, 2019). While the normal path of the game track what designed in white which indicated the normal trajectory. The game track which is light green, light blue, light yellow, and pink is the box to get the question card. The question card was designed with a size of $6 \mathrm{~cm} \mathrm{x}$ $9 \mathrm{~cm}$ which contained questions related to the material and also includes an answer key. The following is a sample design of the question cards.
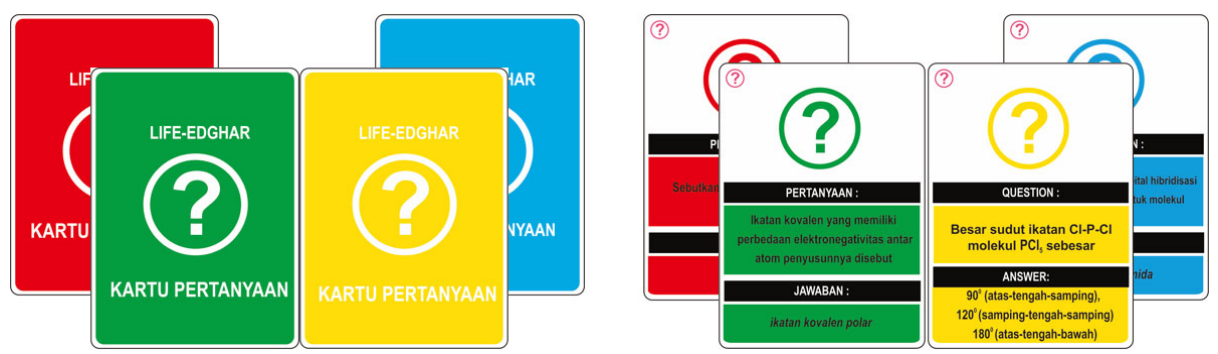

Fig. 3. Design of questions cards 
This learning media is also equipped with information cards which are designed in light green color. This green color was chosen because it can balance emotions and provide hope (Plass et al., 2020), so students can be open to communicating in learning. On the inside of this card there is the name of the molecule and the molecular shapes marker that can be scanned using the application, which will display the 3D shape of the molecule in Augmented Reality. Here is a sample design of the information card:

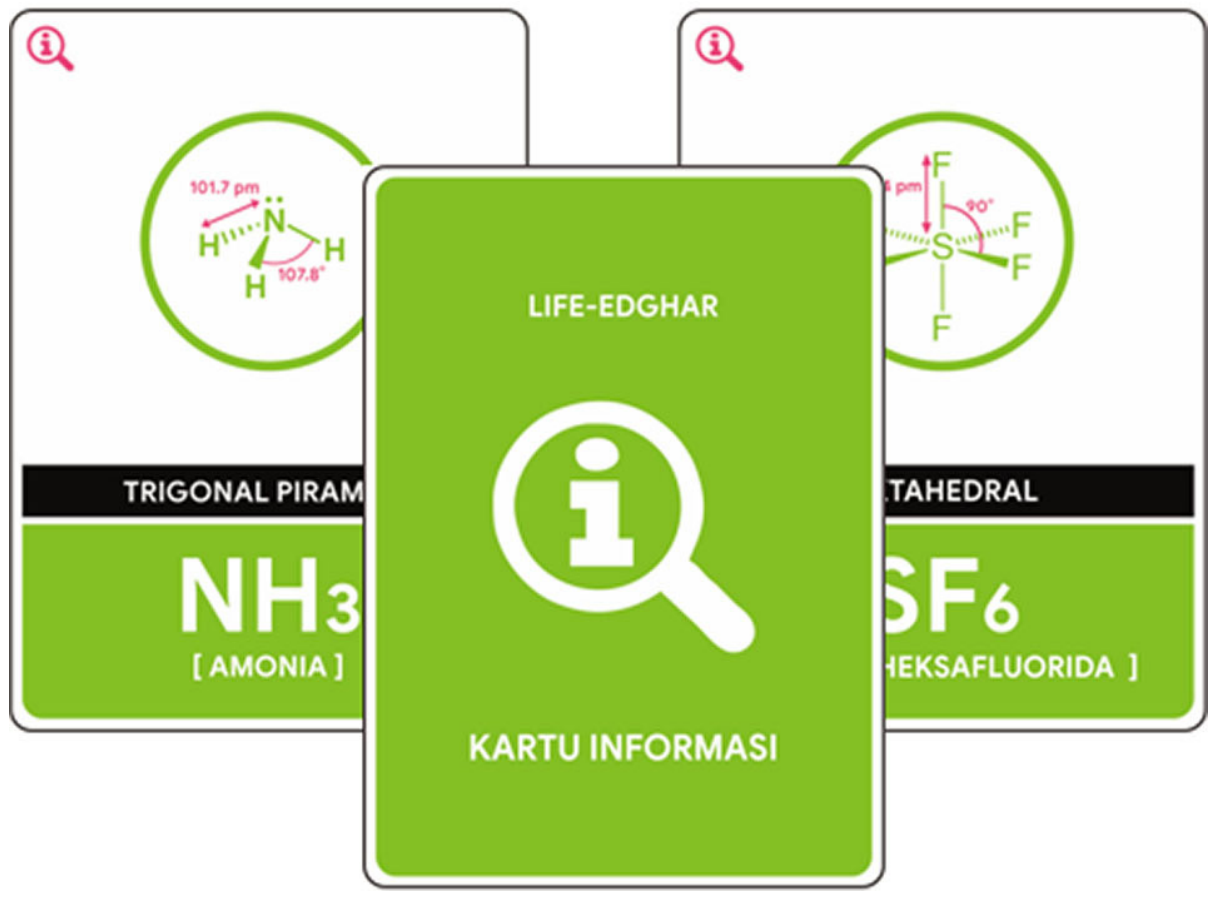

Fig. 4. Design of information cards

Similar to the question card, the information card was also designed with a size of $6 \mathrm{~cm} \times 9 \mathrm{~cm}$ for easy handling. In addition, there is also a more information card containing a barcode that is directly connected to the media blog when scanned. This card contains three barcodes, namely the design, the game flow, and the download link for the learning media application. To display Augmented Reality on information cards that contain markers, a learning media application is made. This application was created with the Unity Pro application, while the 3D object was created with Blender. The design of more information card can be seen below: 


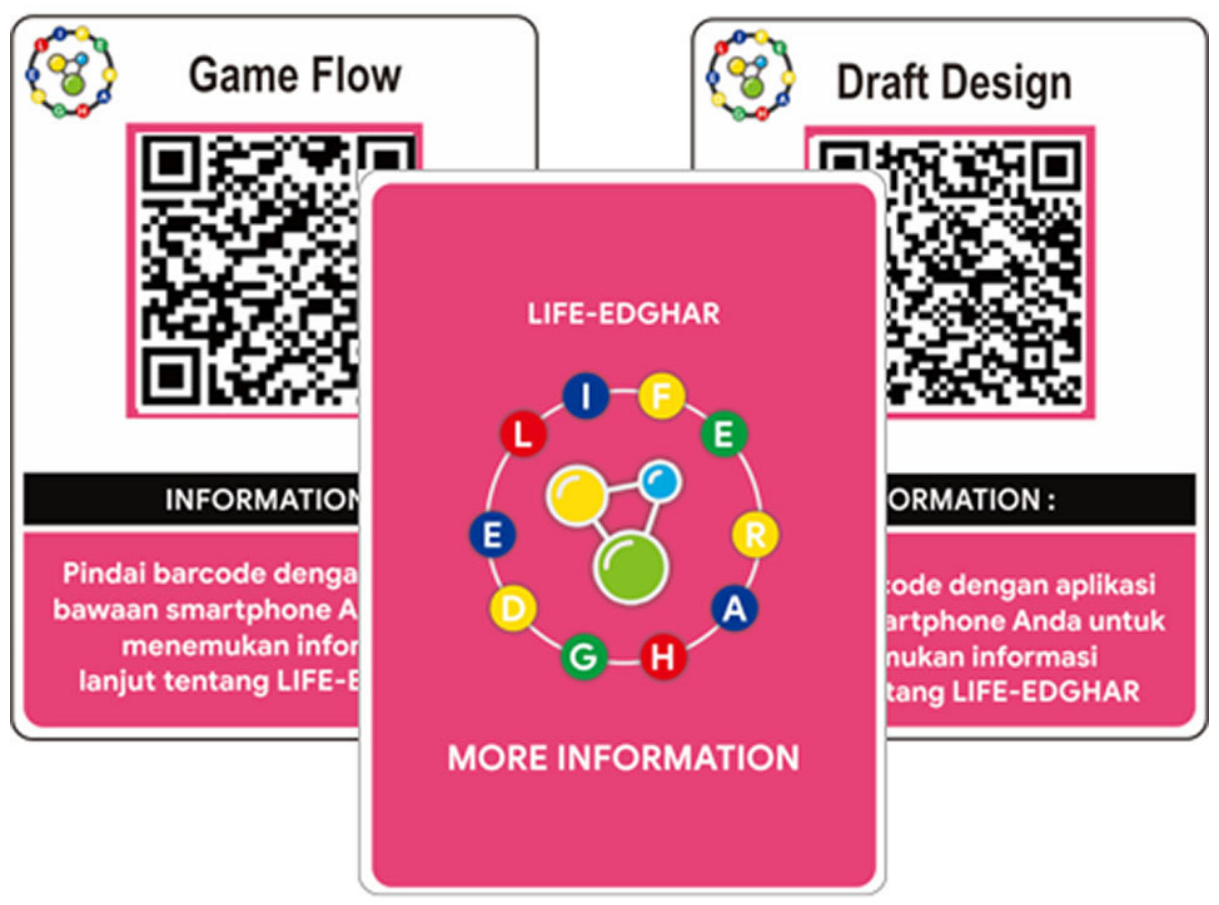

Fig. 5. Design of more information card

In line with the above, physical learning media was also equipped with a hologram feature consisting of a 16-second holographic video. This video was created by recording an animation of the molecular shapes obtained from ChemDraw or ChemSpider, then edited into a four-sided video on one screen. In addition, holographic glass prisms were also made, as well as manual book of media as a guide for teachers when applying this learning media.

a)

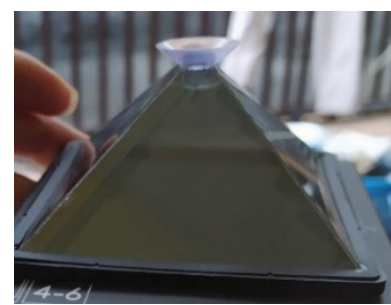

b)

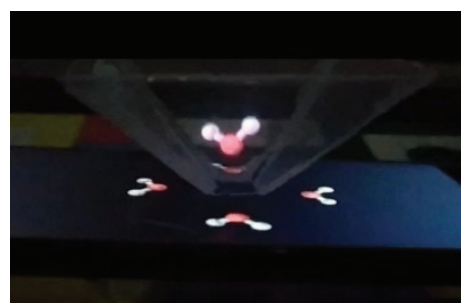

Fig. 6. (a) Holographic glass prisms, and (b) Hologram display 


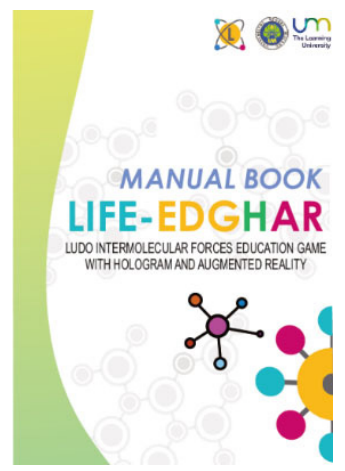

Fig. 7. Manual book

\subsection{Application of learning media}

This learning media application was exported in .apk format which has a size of approximately $23 \mathrm{MB}$. Files can be directly installed and connected with android devices. On the start page of the application, the first thing that students saw after opening this learning media application was the loading page first when the application was first loaded. The loading page is intended to provide time for the application to load the existing content in its entirety. The start page of the application is followed by a splash screen page with a display according to Figure 8 . There was an animated image of laboratory equipment with a light blue background that shows the identity of the media and the "Scan the Card" and "Close the App" buttons. This blue color was used as the basic color because it can to calm the mind and increase student concentration when opening the application (Atikah Roslan \& Alwi Syed Abu Bakar, 2019). In addition, there is also a logo from the learning media which is red and is circled by the words LIFE-EDGHAR whose letters are in red, yellow, blue, and green in the form of a circle. This color selection was chosen to match the color combinations of the game board and cards on the physical learning media.

a)

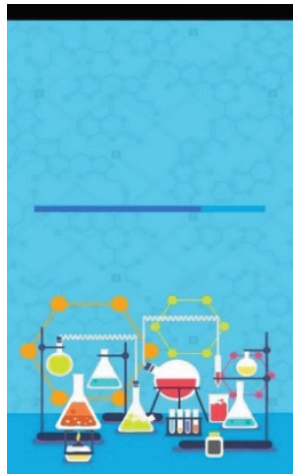

b)

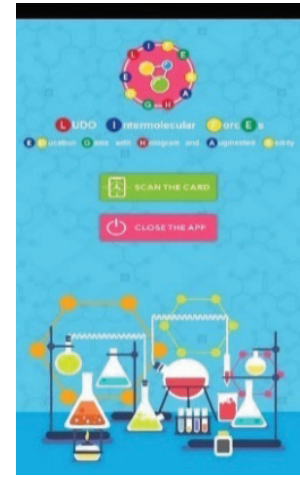

Fig. 8. (a) Loading page, and (b) main menu of application 
As for using the developed media application, students can select the "Scan the Card" button on the splash screen page to be able to scan the barcode/marker on the information card to see the Augmented Reality display of a certain molecular shape. When running this application, users can to listen the application's background music which aims to make the game atmosphere and the learning process more fun. In addition, to exit the application, students only need to press the "Close the App" button and the application will automatically close by itself.

\subsection{Game concept of learning media}

This learning media can be played by a maximum of four students for one game. Each game can be accompanied by a teacher. The media game begins with the teacher opening the class as usual. Then the teacher gives a little description of the rules of the game and a brief explanation of the material of molecular shapes. Before starting the lesson, students get a little information about the shape of the molecule through playing a holographic video that will display a 3D projection in a hologram. Next, the teacher invites students to play by first dividing students into groups. After that, students determine the turn of the game with their respective opponents, then are welcome to start the game by throwing the dice and will cross the trajectory of the game board as shown below:

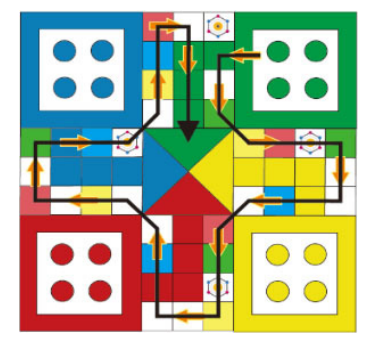

Fig. 9. Game track

Students can to get out of the home box if they get the number 6 dice, after which they can travel according to the dice numbers obtained. If students stop in the white box, they are in a safe position and can continue their journey on the next turn. However, if a student's pawn stops in a red, green, blue, or yellow box, he/she will get a question card according to the color of the box. Students are given the opportunity to answer questions from the question card which read by their opponents. If the student cannot answer the question or give the wrong answer, then the student's pawn returns to its original position (last position before getting the question card), and will not be able to start the next turn before getting an answer from the question card, whereas if the student can answer questions, then the position remains in the colored box and can continue the journey on the next turn. If the student's pawn stops at the molecule picture box, the student will get an information card containing additional material in the form of a molecule in the form of a 3-dimensional display on Augmented Reality as shown below: 

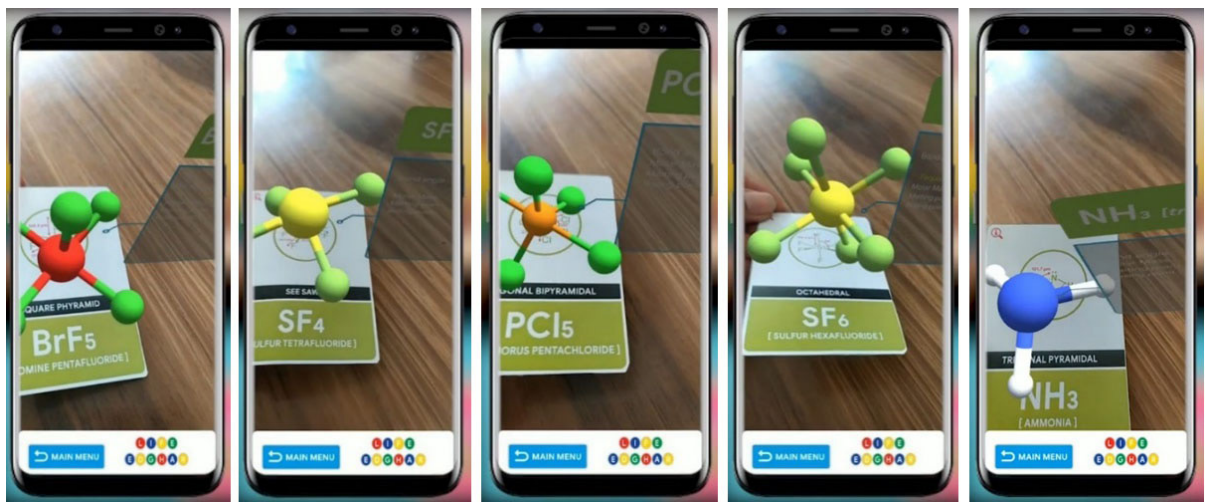

Fig. 10. Augmented reality display

Students take the available information cards, then open the media application, then open the Play menu and scan the information card. In this way, students get information as shown in Figure 10 above. The use of information cards that can make players aware of molecular information aims to later be able to answer questions on the question card. Then, the student who first collects his four pawns to the center box is the winner of the game, while the next winner is determined by the order of the player's speed in collecting his four pawns to the center box.

\subsection{Learning model for media implementating in the classroom}

This learning media is suitable to be applied in the classroom using the Teams Games Tournament (TGT) learning model, because there are elements of fun games in learning (Yunanda et.al, 2018). This learning model was initiated by Robert Slavin, and contains two main perspectives: motivational and cognitive (Slavin, 1987). In (Shoimin, 2014), the TGT learning steps are: (1) Class Presentation, (2) Teams, (3) Games, (4) Tournament, and (5) Team Recognition. In stages 1 and 2, the teacher delivers the material and divides the students into several groups. The use of this learning media is carried out at the games and tournament stages, the difference lies in the time and purpose of use. At the games stage, the media is used as a complement to teaching/materials as well as being used to collect points that will be used at the tournament stage. The tournament stage is carried out by students who have the highest points in their group and will compete with representatives of other groups. At this stage the use of media is more em phasized to evaluate or test students' understanding of the material that has been studied. Later, the team that has the highest points will be the winner and will get a prize if the points achieved meet the predetermined criteria. This is the importance of the recognition stage to appreciate the student's learning process (Kamaruddin \& Yusoff, 2019). 


\subsection{Product feasibility as learning media}

The feasibility of the product as a learning media was obtained from the results of filling out a questionnaire which filled out by media experts, namely the Head of the Indonesian Graphic Design Association (ADGI) chapter Malang and two chemistry teachers at SMAN 1 Turen. The results of product development validation in terms of learning media are presented in Table 2 below:

Table 2. Results of validation of development products as learning media

\begin{tabular}{|l|l|c|l|}
\hline \multicolumn{1}{|c|}{ No } & \multicolumn{1}{|c|}{ Indicator } & Percentage (\%) & \multicolumn{1}{c|}{ Criteria } \\
\hline 1. & Overall view of physical media & 86.67 & Highly feasible/valid \\
\hline 2. & Question cards display & 81.67 & Highly feasible/valid \\
\hline 3. & Information cards display & 85.00 & Highly feasible/valid \\
\hline 4. & Application menu display & 88.89 & Highly feasible/valid \\
\hline \multicolumn{2}{|l|}{ Average Percentage } & $\mathbf{8 5 . 5 6}$ & Highly feasible/valid \\
\hline
\end{tabular}

Based on the data above, the average percentage of product validation results as a learning medium is $85.56 \%$. When compared with the eligibility criteria in Table 1 , the product development as a learning media is included in the very valid criteria and very feasible to use. The advice given is to enlarge the size of the card and writing and add information about system requirements on the card package so that users know the minimum requirements for device/android specifications to be able to use the application.

\subsection{Product feasibility in terms of material}

This learning media was also validated in terms of material. The validation of this material was carried out by a Lecturer of Inorganic Chemistry, State University of Malang, and two chemistry teachers of SMAN 1 Turen, the following results were obtained:

Table 3. Results of validation of development products as learning media

\begin{tabular}{|l|l|c|l|}
\hline \multicolumn{1}{|c|}{ No. } & \multicolumn{1}{|c|}{ Indicator } & Percentage (\%) & \multicolumn{1}{c|}{ Criteria } \\
\hline 1. & $\begin{array}{l}\text { The suitability of the questions on } \\
\text { the question card }\end{array}$ & 93.33 & Highly feasible/valid \\
\hline 2. & $\begin{array}{l}\text { The conformity of the shape of the } \\
\text { molecule on the hologram }\end{array}$ & 86.67 & Highly feasible/valid \\
\hline 3. & $\begin{array}{l}\text { The suitability of the molecular } \\
\text { shape on the application }\end{array}$ & 86.67 & Highly feasible/valid \\
\hline 4. & $\begin{array}{l}\text { The suitability of the molecular } \\
\text { information on the application }\end{array}$ & 80.00 & Feasible/valid \\
\hline 5. & $\begin{array}{l}\text { Conformity of information on the } \\
\text { information card }\end{array}$ & 93.33 & Highly feasible/valid \\
\hline & Average Percentage & $\mathbf{8 8 . 0 0}$ & Highly feasible/valid \\
\hline
\end{tabular}


Based on the table above, the average results of media validation in terms of material are $88.00 \%$, which means that this learning media is very valid and very feasible in terms of material to improve understanding of concepts in students in learning molecular shapes for Grade $10^{\text {th }}$ Senior High School/equivalent students. The suggestions given are more emphasized in order to add a variety of questions.

\subsection{Results of small group trials}

Small group trials were conducted using a revised development product based on comments and suggestions from the validators. The test subjects were 17 students of Grade $10^{\text {th }}$ MIPA 3 SMAN 1 Turen and got the following results:

Table 4. Results of small group trials

\begin{tabular}{|l|l|c|l|}
\hline \multicolumn{1}{|c|}{ No. } & \multicolumn{1}{|c|}{ Indicator } & Percentage (\%) & \multicolumn{1}{c|}{ Criteria } \\
\hline 1. & Media presentation & 88.24 & Highly feasible/valid \\
\hline 2. & Information clarity & 84.31 & Highly feasible/valid \\
\hline 3. & Use of media and application programs & 86.27 & Highly feasible/valid \\
\hline 4. & Media effectiveness (in students' perception) & 90.29 & Highly feasible/valid \\
\hline \multicolumn{2}{r|}{ Average Percentage } & $\mathbf{8 7 . 2 5}$ & Highly feasible/valid \\
\hline
\end{tabular}

The small group trials was carried out obtained an average percentage result of $87.25 \%$, so it can be concluded that this learning media is very valid or very feasible according to students' perceptions as potential media users. Of the four criteria assessed, the effectiveness of the media got the largest percentage, namely $90.29 \%$, which means that most students feel motivated, happy, interested, and make it easier for them to learn according to their perceptions while using this media. The comments given by most of the students emphasized the ease of installing the application and adding information to the Augmented Reality feature.

\section{Conclusion}

The components of the learning media based on Augmented Reality, Hologram, and ludo game on the molecular shapes material include: (1) ludo game board, (2) pawns, (3) dice, (4) question cards, (5) information cards, (6) more information cards, (7) holographic glass prisms, (8) holographic videos, (9) manual book, and (10) applications for displaying 3D Augmented Reality objects. The concept of the media game is almost the same as the usual ludo game. It's just that there are colored boxes and molecular boxes that require players to get question cards and information in the form of Augmented Reality. In addition, material reviews in the form of holograms are also given to players before starting the game. The average percentage of media validation results as learning media and in terms of material were $85.56 \%$ and $88.00 \%$, respectively. While the small group trial on 17 students of SMAN 1 Turen got a result of $87.25 \%$, so it can be concluded that this learning media wass declared very feasible to be implemented. This can create a more pleasant learning atmosphere and make it easier for students 
to understand molecular shapes. However, the use of this learning media has not been tested for its effectiveness in learning. Therefore, further research can to examine the effect of using this media on students' interest and understanding of concepts in molecular shapes material, such as conducting experiments on the influence of media on increasing motivation, student learning outcomes using the Teams Games Tournament (TGT) learning model.

\section{$5 \quad$ Acknowledgment}

This development research was assisted by the State University of Malang for funding this research and SMA Negeri 1 Turen for data collection. Thank you very much to those who have assisted in this development research, especially to students at the SMA Negeri 1 Turen.

\section{References}

[1] Agustina Dwi Astuti, I., Asep Sumarni, R., \& Luhur Saraswati, D. (2017). Pengembangan Media Pembelajaran Fisika Mobile Learning berbasis Android. JPPPF-Jurnal Penelitian Dan Pengembangan Pendidikan Fisika, 3(1), 57-62. https://doi.org/10.21009/1

[2] Andreas, D. (2013). Cara Merancang Storyboard untuk Animasi Keren. Yogyakarta: Taka.

[3] Anwar, S. (2014). Pengembangan Bahan Ajar. Bandung: FPMIPA Universitas Pendidikan Indonesia.

[4] Arsyad, A. (2014). Media Pembelajaran. Jakarta: Rajawali Press.

[5] Asyhari, A., \& Silvia, H. (2016). Pengembangan Media Pembelajaran Berupa Buletin dalam Bentuk Buku Saku untuk Pembelajran IPA Terpadu. Jurnal Ilmiah Pendidikan Fisika Al-Biruni, 5(1), 1-13. https://doi.org/10.24042/jpifalbiruni.v5i1.100

[6] Atikah Roslan, A., \& Alwi Syed Abu Bakar, S. (2019). Warna Kontemporari Dalam Karya Seni. Idealogy, 3(4), 1-13. https://doi.org/10.24191/idealogy.v4i2.143

[7] Ayni. (2019). Pengaruh Pendekatan Pencapaian Konsep terhadap Pemahaman Konsep Materi Bentuk Molekul di SMA. Pontianak.

[8] Carrozzi, A., Chylinski, M., Heller, J., Hilken, T., Keeling, D. I., \& de Ruyter, K. (2019). What's Mine Is a Hologram? How Shared Augmented Reality Augments Psychological Ownership. Journal of Interactive Marketing, 48, 71-88. https://doi.org/10.1016/j. intmar.2019.05.004

[9] Fadillah, A. R. (2019). EduKimia Journal Efektivitas Penggunaan Media Pembelajaran Permainan Ludo Kimia Berbasis Chemo-Edutainment (CET) pada Materi Struktur Atom terhadap Hasil Belajar Siswa Kelas X SMA N 3 Padang The Effectivity an Instructional Media of Ludo Game Based on Chemo-Edutainment (CET) for Atomic Structure Toward 1 st Grade Students Achievement from SMA N 3 Padang. 1. Retrieved from http:// edukimia.ppj.unp.ac.id/ojs/index.php/edukimia/ARTIKELRISET; https://doi.org/10.24036/ ekj.v1.i3.a76

[10] Fitriani, E., Suhartono, S., \& Mugiarti, I. (2019). Make It Real: Simulation of 3D Molecules Using Augmented Reality in Chemical Bonding Topic. Journal of Physics: Conference Series, 1402(5). Institute of Physics Publishing. https://doi.org/10.1088/1742-6596/1402/5/055058

[11] Hayati, N. (2020). Analisis Pemahaman Konsep Peserta Didik pada Materi Bentuk Molekul Menggunakan Four-Tier Diagnostic Test. Banda Aceh. 
[12] Kamaruddin, S., \& Yusoff, N. M. R. N. (2019). The Effectiveness of Cooperative Learning Model Jigsaw and Team Games Tournament (TGT) towards Social Skills. Creative Education, 10(12), 2529-2539. https://doi.org/10.4236/ce.2019.1012180

[13] Kristiani, D. (2015). Ensiklopedia Negeriku (Permainan Tradisional). Jakarta: Bhuana Ilmu Populer.

[14] Lee, W. W., \& Owens, D. L. (2004). Multimedia-Based Instructional Design (2nd ed.). San Fransisco: Pfeiffer.

[15] Lestari, R., \& Iswendi. (2021). Pengembangan Permainan Ludo Kimia sebagai Media Pembelajaran pada Materi Asam dan Basa Kelas XI SMA/MA. Ranah Research: Journal of Multidicsiplinary Research and Development, 3(2), 48-55. Retrieved from https://jurnal. ranahresearch.com; https://doi.org/10.24036/ekj.v3.i1.a211

[16] Naibaho, M. E. (2015). Pengantar Pendidikan. Medan: FKIP Universitas HKBP Nommensen.

[17] Nurdin, F., \& Sulastry, T. (2018). Pengaruh Penggunaan Media Pembelajaran Berbasis Macromedia Flash 8 pada Model Pembelajaran Kooperatif Melalui Pendekatan Saintifik Terhadap Motivasi dan Hasil Belajar (Study pada Materi Pokok Laju Reaksi). Chemistry Education Review (CER), Pend. Kimia PPS UNM, 1(2), 29-43. https://doi.org/10.26858/cer. $\underline{\mathrm{v} 0 \mathrm{i} 1.5607}$

[18] Plass, J. L., Homer, B. D., MacNamara, A., Ober, T., Rose, M. C., Pawar, S., ... Olsen, A. (2020). Emotional Design for Digital Games for Learning: the Effect of Expression, Color, Shape, and Dimensionality on the Affective Quality of Game Characters. Learning and Instruction, 70. https://doi.org/10.1016/j.learninstruc.2019.01.005

[19] Riduwan. (2012). Pengantar Statistika Sosial. Bandung: Alfabeta.

[20] Riku, M. (2021). Meningkatkan Hasil Belajar Siswa Kelas X IPA Pada Materi Bentuk Molekul Melalui Model Pembelajaran Discovery Learning Berbantuan Phet Simulations. Secondary: Jurnal Inovasi Pendidikan Menengah, 1(2), 79-87. https://doi.org/10.51878/ secondary.v1i2.132

[21] Saregar, A., Hadiati, E., Syafe'i, I., Septiani, R., \& Widayanti, W. (2019). Developing Web-Enhanced Course in Basic Electronic Course. Journal of Physics: Conference Series, 1155(1). Institute of Physics Publishing. https://doi.org/10.1088/1742-6596/1155/1/012094

[22] Shoimin, A. (2014). 68 Model Pembelajaran Inovatif dalam Kurikulum 2013. Yogyakarta: Ar-Ruzz Media.

[23] Siregar, E., \& Nara, H. (2014). Teori Belajar dan Pembelajaran. Jakarta: Ghalia Indonesia.

[24] Slavin, R. E. (1987). Developmental and Motivational Perspectives on Cooperative Learning: A Reconciliation. Source: Child Development, 58(5), 1161-1167. https://doi. org $/ 10.2307 / 1130612$

[25] Solihin, D. (2017, May 2). Memuliakan Pendidikan, Sudahkah? https://doi.org/10.32332/ tarbawiyah.v2i02.1403

[26] Yuberti, Y., Sairi, A. P., Nanto, D., \& Sholeha, S. (2020). Physics Ludo Integrated With Scientific Literacy as a Newton's Law Learning Media. Journal of Physics: Conference Series, 1572(1). Institute of Physics Publishing. https://doi.org/10.1088/1742-6596/1572/1/012051

[27] Yunanda, H., Advinda, L., \& Sumarmin, R. (2018). Effects of Cooperative Learning Model Type Games Teams Tournament (TGT) and Entry Behavior Student to Learning Competence Class XI IPA Senior High School 1 Lengayang. International Journal of Progressive Sciences and Technologies (IJPSAT), 6(2), 329-339. Retrieved from http://ijpsat. ijsht-journals.org 


\section{Authors}

Rifqon Hakiki is a bachelor of chemistry education, Universitas Negeri Malang. $\mathrm{He}$ is currently working as a learning designer in a retail company in Indonesia (email: rifqon.hakiki.1703316@students.um.ac.id).

M. Muchson is a faculty in Department of Chemistry, Universitas Negeri Malang. $\mathrm{He}$ is currently doing his $\mathrm{PhD}$ in Science Education at Mallinson Institute for Science Education, Western Michigan University, United States of America (email: m.muchson. fmipa@um.ac.id).

Oktavia Sulistina is a lecturer in the field of chemistry education at the Universitas Negeri Malang, Indonesia. She is active in writing scientific papers, researching, and developing learning innovation in chemistry. Beside that she is involved as an instructor of national educator certification. (e-mail: oktavia.sulistina.fmipa@um.ac.id)

Asia Febriana is a bachelor of chemistry education who likes challenges and interested in the world of learning innovation. (email: asia.febriana.1703316@students. um.ac.id).

Article submitted 2021-12-18. Resubmitted 2022-01-21. Final acceptance 2022-01-23. Final version published as submitted by the authors. 